\title{
Bearing of Cytology on the Systematic Position of Ixiolirion (Fischer) Herb. (Amaryllidaceae)
}

\author{
J. L. Karihaloo and A. K. Koul \\ Department of Biosciences, University of Jammu, \\ Jammu, India
}

Received September 8, 1982

Despite the fact that Amaryllidaceae has been a favourite plant group for cytotaxonomic studies, little attention has been paid to Ixiolirion (Fischer) Herb., a small but distinct genus of the family. On the basis of morphological description, Ixiolirion was placed in subfamily Agaveae of Amaryllidaceae by Herbert (1837). Subsequently, Benthem and Hooker (1883) and Baker (1888) referred it to subfamily Alstroemerieae of the same family. Hutchinson in 1934 raised, among others, orders Agavales and Alstroemeriales distinct from Amaryllidales and placed Ixiolirion within the latter as the only member of tribe Ixiolirieae of family Amaryllidaceae (Hutchinson 1959). Traub (1957) followed Hutchinson in placing the genus in Amaryllidaceae but recognizing its somewhat different morphology from other members of the family, raised it to the status of a subfamily, Ixiolirioideae. This position has been maintained by Takhtajan in a more recent classification of angiosperms (Takhtajan 1980).

Species delimitation in Ixiolirion has been quite controversial. While some systematists have named as many as five species and several varieties (see for example Komarov 1935, Traub 1942, Wendelbo 1970, Nasir 1980), Traub (1942) recognized just one, I. tataricum.

The two problems that seek solution are: phylogeny of the genus Ixiolirion, and its species composition. Hitherto the only information available on cytology of the genus is chromosome numbers of two taxa (Traub 1942, Murin and Sheikh 1971). These reports put the $2 \mathrm{n}$ number at 24 . During the present study chromosome complement and male meiosis of 1 . tataricum (Pall.) Herb., growing wild in saffron fields of Kashmir, were studied for eliciting information on the two problems pointed above.

\section{Materials and methods}

Plants of $I$. tataricum were collected from saffron fields in Pampore, Kashmir. Root tips were obtained by sowing bulbs in moist sand. About $1 \mathrm{~cm}$ long tips were prefixed in a saturated solution of paradichlorobenzene for $3 \mathrm{hr}$ at $10^{\circ} \mathrm{C}$ and later fixed in $1: 3$ acetic alcohol solution. The root tips were hydrolysed in $9: 1$ acetoorcein: $\mathrm{NHCl}$ mixture and squashed in $1 \%$ acetoorcein. For meiosis flower buds were fixed in a solution of 1 acetic acid: 1 alcohol: 1 chloroform for 4-12 hr. Chromosome classification proposed by Battaglia (1955) has been followed. The terms metacentric (chromosomes with median centromere), submetacentric (chromosomes 
with submedian centromere) and acrocentric (chromosomes with subterminal centromere) have also been used.

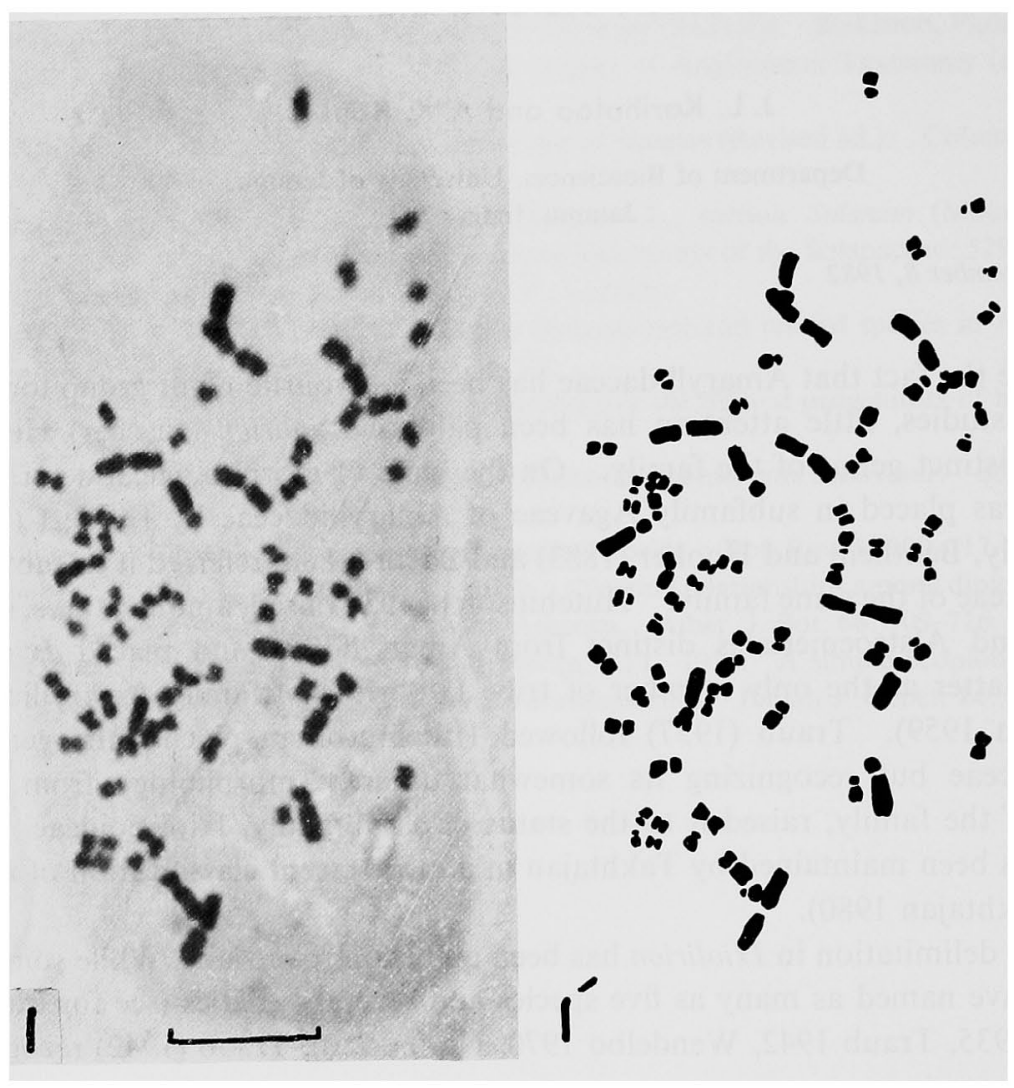

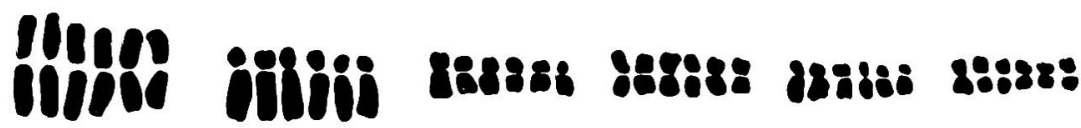

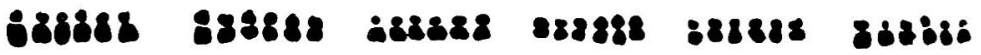 \\ 2}

Figs. 1-2. 1, somatic chromosomes; $1^{\prime}$, explanatory diagram to Fig 1. 2, karyoidiogram of hexaploid population of Ixiolirion tataricum showing 72 chromosomes. Scale $10 \mu$.

\section{Observations}

Morphology: Plants $25-48 \mathrm{~cm}$ tall bulbous perennials, bulbs ovoid, covered with dark brown coriaceous coats; basal leaves $3-5$, forming a tuft at the soil surface, linear, flat, slightly grooved; scape $21-31 \mathrm{~cm}$ long with $0-2$ leaves; flowers $2-5$ in 
1-2 small and loose umbels, spathaceous, bracts lanceolate, each subtending a pedicellate flower; flowers broadly infundibuliform, $2.3-2.8 \mathrm{~cm}$ long and $2.4-3.1 \mathrm{~cm}$ across; perianth tube absent, lobes reflexed above, blue violet with prominent white band running down the whole length on the inner side; stamens fixed near the base of

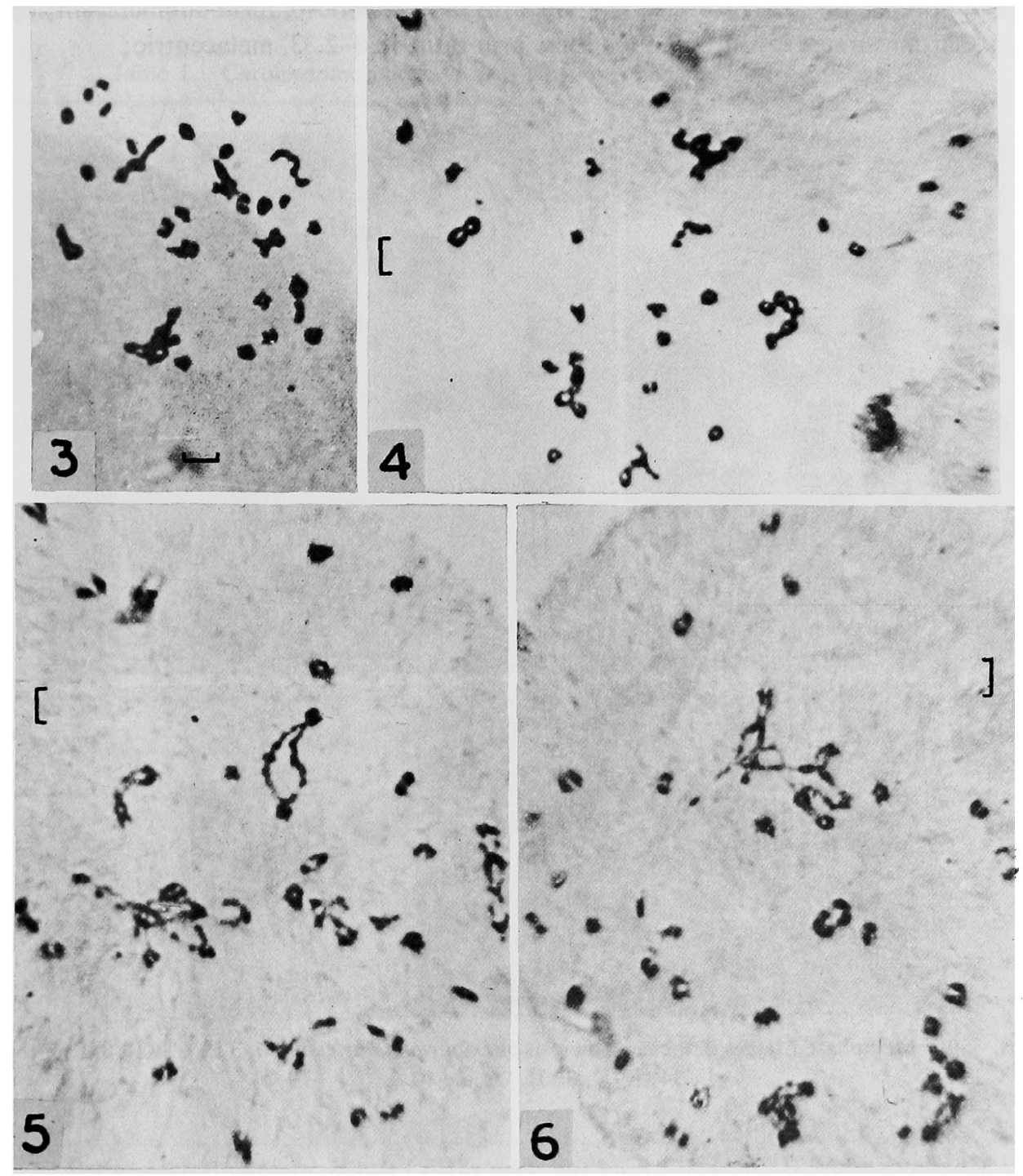

Figs. 3-6. Diplotene-diakinesis stages in the male meiosis of Ixiolirion tataricum. $3,3 \mathrm{VI}+3$ IV+1 III+19 II +1 I. 4, 2 VI +2 IV+26 II. 5, $1 \mathrm{VI}+1 \mathrm{IV}+31 \mathrm{II} .6,1 \mathrm{VI}+1 \mathrm{IV}+30 \mathrm{II}+2 \mathrm{I}$. Scale $10 \mu$.

perianth; anthers basifixed, ovary inferior, ovules 12-15 per locule.

Karyotype: Root tip cells of all plants scanned for cytology contained 72 chromosomes (Figs. 1-2) ranging between 0.9-5.8 $\mu$. On the basis of their length and arm ratio the chromosomes form 12 groups of 6 chromosomes each. The first two 
groups include 12 long chromosomes designated here as L type, the remaining 10 groups consisting of short chromosomes are collectively referred to as the $\mathrm{S}$ type.

$\mathrm{L}_{1}$ : Chromosomes 1-6, 4.8-5.8 $\mu$ long, arm ratio 1.09-1.22, meta-submetacentric; $\mathrm{L}_{2}$ : Chromosomes $7-12,3.4-4.2 \mu$ long, arm ratio $2.78-3.67$, submeta-acrocentric;

$\mathrm{S}_{1}$ : Chromosomes 13-18, 1.9-2.2 $\mu$ long, arm ratio 1.63-2.14, submetacentric;

$\mathrm{S}_{2}$ : Chromosomes 19-24, 1.8-2.3 $\mu$ long, arm ratio 1.09-1.40, meta-submetacentric; $\mathrm{S}_{3}$ : Chromosomes 25-30, 1.5-2.0 $\mu$ long, arm ratio 1.38-2.33, metacentric;

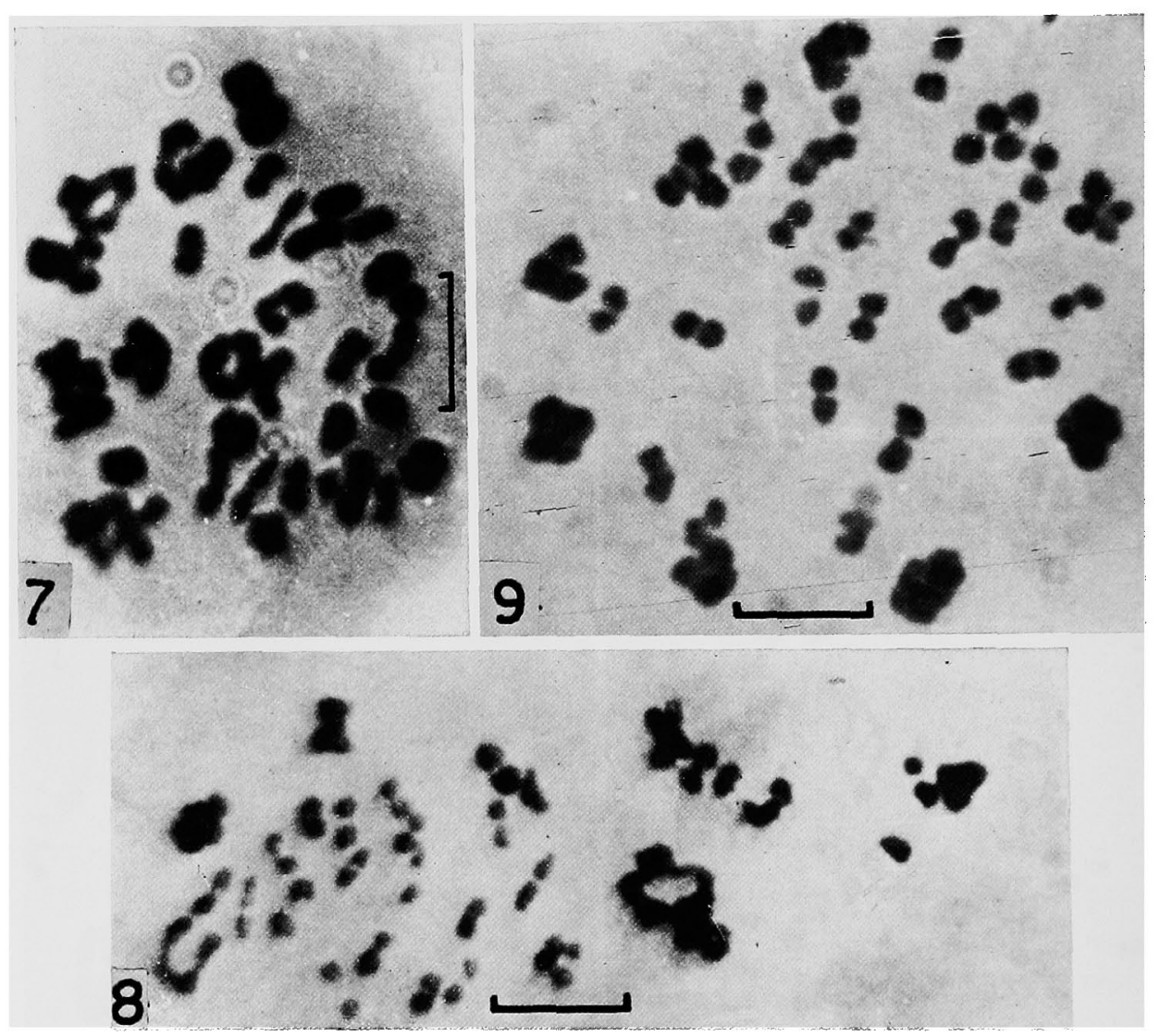

Figs. 7-9. Metaphase I stages in the male meiosis of Ixiolirion tataricum. 7, 3 IV +30 II. 8, 1 IV + 34 II. 9, 36 II. Scale $10 \mu$.

$\mathrm{S}_{4}$ : Chromosomes 31-36, 1.5-1.8 $\mu$ long, arm ratio 1.0-1.5, meta-submetacentric;

$\mathrm{S}_{5}$ : Chromosomes 37-42, 1.4-1.6 $\mu$ long, arm ratio 1.29-1.33, submetacentric;

$\mathrm{S}_{6}$ : Chromosomes 43-48, 1.4-1.5 $\mu$ long, arm ratio $1.0-1.14$, meta-submetacentric;

$\mathrm{S}_{7}$ : Chromosomes 49-54, 1.3-1.5 $\mu$ long, arm ratio $1.25-1.60$, submetacentric;

$\mathrm{S}_{8}$ : Chromosomes 55-60, 1.2-1.4 $\mu$ long, arm ratio $1.0-1.17$, meta-submetacentric;

$\mathrm{S}_{8}$ : Chromosomes 61-66, 1.0-1.3 $\mu$ long, arm ratio $1.50-1.75$, submetacentric;

$\mathrm{S}_{10}$ : Chromosomes $67-72,0.9-1.2 \mu$ long, arm ratio $1.25-1.75$, submetacentric.

Karyotype formula : $6 \mathrm{~L} \mathrm{Me}-\mathrm{Sm}+6 \mathrm{~L} \mathrm{Sm}-\mathrm{St}+36 \mathrm{~S} \mathrm{Sm}+24 \mathrm{~S} \mathrm{Me}-\mathrm{Sm}$. 
Male meiosis: Flower buds of $I$. tataricum undergo male meiosis some 2-3 weeks before their opening. On account of high number and small size of chromosomes, early stages of meiosis were not quite compromising.

At diplotene-diakinesis, majority of the chromosomes were involved in bivalent associations, nonetheless some multivalent associations were found in all well spread cells (Figs. 3-6). The 17 pollen mother cells scored for chromosome configurations

Table 1. Chromosome associations at diplotene-diakinesis in I. tataricum

\begin{tabular}{|c|c|c|c|c|c|c|c|c|}
\hline \multirow{2}{*}{ S. no. } & \multicolumn{6}{|c|}{ Associations } & \multirow{2}{*}{$\begin{array}{l}\text { No. of } \\
\text { cells }\end{array}$} & \multirow{2}{*}{ Fig. no } \\
\hline & VI & $\mathrm{V}$ & IV & III & II & I & & \\
\hline 1 & 3 & - & 3 & 1 & 19 & 1 & 1 & 3 \\
\hline 2 & 2 & - & 3 & - & 24 & - & 1 & \\
\hline 3 & 2 & - & 2 & - & 26 & - & 2 & 4 \\
\hline 4 & 2 & - & 1 & - & 28 & - & 1 & \\
\hline 5 & 1 & 1 & 1 & 1 & 26 & 2 & 1 & \\
\hline 6 & 1 & - & 2 & - & 29 & - & 1 & \\
\hline 7 & 1 & - & 1 & - & 31 & - & 1 & 5 \\
\hline 8 & 1 & - & 1 & - & 30 & 2 & 1 & 6 \\
\hline 9 & - & - & 4 & 1 & 26 & 1 & 1 & \\
\hline 10 & - & - & 3 & - & 30 & - & 5 & \\
\hline 11 & - & - & 2 & 1 & 30 & 1 & 1 & \\
\hline 12 & - & - & 1 & 1 & 32 & 1 & 1 & \\
\hline Total & 15 & 1 & 38 & 5 & 411 & 8 & 17 & \\
\hline
\end{tabular}

Table 2. Chromosome associations at metaphase I in I. tataricum

\begin{tabular}{ccccccccc}
\hline & \multicolumn{9}{c}{ Associations } & \multicolumn{2}{c}{$\begin{array}{c}\text { No. of } \\
\text { S. no. }\end{array}$} & VI & V & IV & III & II & I & Fig. no. \\
\cline { 2 - 9 } & 1 & - & 1 & - & 31 & - & 3 & \\
\hline 1 & 1 & - & - & - & 33 & - & 1 & \\
2 & - & 1 & - & - & 33 & 1 & 1 & \\
4 & - & - & 3 & - & 30 & - & 2 & 7 \\
5 & - & - & 2 & - & 32 & - & 6 & \\
6 & - & - & 1 & - & 34 & - & 11 & 8 \\
7 & - & - & 1 & - & 32 & 4 & 1 & \\
8 & - & - & - & 1 & 34 & 1 & 1 & \\
9 & - & - & - & - & 36 & - & 16 & 9 \\
10 & - & - & - & - & 34 & 4 & 7 & \\
11 & - & - & - & - & 32 & 8 & 1 & \\
\hline Total & 4 & 1 & 33 & 1 & 1691 & 42 & 50 & \\
\hline
\end{tabular}

carried an average of $0.88 \mathrm{VI}, 0.06 \mathrm{~V}, 2.24 \mathrm{IV}, 0.29 \mathrm{III}, 28.06 \mathrm{II}$ and $0.47 \mathrm{I}$ (Table 1 ). Upto 3 hexavalents and 4 quadrivalents were observed in cells at diplotene. The univalents ranged from 1 to 2 per cell. Chiasmata were found randomly distributed in all chromosome associations.

By the time metaphase I was reached, multivalent frequency reduced with a proportionate increase in bi- and univalent frequencies. The 50 metaphase spreads 
scored for chromosome associations (Figs. 7-9) carried on an average 0.08 VI, $0.02 \mathrm{~V}, 0.66 \mathrm{IV}, 0.02 \mathrm{III}, 33.94 \mathrm{II}$ and $0.84 \mathrm{I}$ (Table 2). The maximum number of hexavalents and quadrivalents observed in any pollen mother cell was 1 and 3 respectively.

Of the 40 pollen mother cells scored at anaphase I (Table 3 ), 18 followed regular (36:36) chromosome segregation. In 12 cells the distribution was $35: 37$; other deviant patterns were rare. Occasionally 1-3 chromosomes were observed lagging at the equatorial plate. Although mature pollen was uniform in size; some micropollen grains $(0.67 \%)$ were also recorded. The latter have their origin in the persistent laggards which first form micronuclei and subsequently differentiate as micropollen grains. Pollen stainability was as high as $90.5 \%$.

Table 3. Anaphase I distribution of chromosomes in I. tataricum

\begin{tabular}{lcccccccc}
\hline & 32 & 34 & 35 & 36 & 34 & 34 & 34 & 35 \\
Distribution pattern & $:$ & $:$ & $:$ & $:$ & 1 & 3 & 2 & 1 \\
& 40 & 38 & 37 & 36 & 37 & 35 & 36 & 36 \\
\hline Number of cells & 1 & 4 & 12 & 18 & 1 & 1 & 1 & 2 \\
\hline
\end{tabular}

\section{Discussion}

Chromosome number

Except for two reports on chromosome numbers of I. tataricum (Traub 1942) and I. montanum (Murin and Sheikh 1971), little is known about the cytology of genus Ixiolirion. These reports indicate that both species are diploid with $2 \mathrm{n}=24$.

Regarding 12 as the base number for the genus, the present population of $I$. tataricum having somatic complement of 72 chromosomes represents a hexaploid. Polyploid nature of this population is reflected in the idiogram wherein chromosomes fall into groups of six. Chromosomes constituting each group exhibit minor size differences, more prominently among the long $\left(\mathrm{L}_{1}\right.$ and $\left.\mathrm{L}_{2}\right)$ than in the short members. As to their arm ratio, chromosomes within each group demonstrate good agreement; $\mathrm{L}_{2}$ and $\mathrm{S}_{3}$ being the only exceptions. When studied in respect of overall size and arm ratios of the chromosomes, Kashmir population of I. tataricum seems to represent a segmental alloploid. Meiotic pairing whereby only $22.06 \%$ chromosomes at diplotene-diakinesis are seen involved in multivalent configurations, the rest remaining as bivalents, supports this conclusion. However, reliability of chromosome morphology and meiotic pairing should not be overemphasized in assessing the nature of polyploidy. Stebbins (1971) regards mitotic chromosomes as mere shells of the genetic material on which too much reliance cannot be laid for interpreting phylogeny. Multivalent frequency as well, does not necessarily speak of the extent of genetic homology between constituent genomes of a polyploid because chromosome pairing is controlled by several other factors such as chromosome length (Stebbins 1950), chiasma localization (Levan 1940), genic multivalent suppression system (Riley and Chapman 1958) B chromosomes (Evans and Macefield 1973) and period of 
establishment (Gilles and Randolph 1951).

Systematic position and interrelationships

With its coloured, trimerous and epigynous flowers borne in scapose umbels, Ixiolirion has rightly been placed in Amaryllidaceae (senu lato). However, its intrafamilial placement is still unresolved. The confusion stems from its unique morphological features in some of which, like the arrangement of flowers in loose umbels or clusters and presence of leaves on the scape, it resembles Alstroemerieae and Agaveae.

Benthem and Hooker (1883) include Ixiolirion in Alstroemerieae alongwith Alstroemeria, Bomarea or Leontochir. Members of the tribe have rhizomatous or tuberous root stock but Ixiolirion has bulbous root system. Karyotype of Ixiolirion has little in common with typical Alstroemerieae. Chromosome numbers of the tribe (Alstroemeriaceae of Darlington and Wylie 1955) are in multiples of 8 and 9. The chromosomes of Alstroemeria are relatively long (4.1-18.6 $\mu$ as calculated from figures drawn by Satô 1938) with 8 of the 16 chromosomes bearing subterminal centromere. The 18 chromosomes of Bomarea group into 4 metacentric and 14 acrocentric. In contrast, Ixiolirion has base number 12, chromosomes are small $(0.9-5.8 \mu)$, and as many as 11 chromosomes of the basic set bear median-submedian centromere. On the basis of root system and karyotype there is hardly any justification for placing Ixiolirion in Alstroemerieae.

With Agaveae too Ixiolirion does not seem to bear a close natural link. Agaves are mostly woody with dry and persistent perianth. Bulk of Agaveae (Agavaceae of Darlington and Wylie 1955) have chromosome numbers in multiples of 30 with characteristic Yucca-Agave type karyotype (Satô 1938) consisting of 5 long and 25 short acrocentric chromosomes. The ratio between long and short chromosomes is as high as 13:1. In these features Ixiolirion differs from majority of Agaveae. The overall evidence of cytology and plant morphology does not, therefore, justify inclusion of Ixiolirion in either Alstroemerieae or Agaveae.

Among the remaining epigynous Amaryllidaceae (sensu Hutchinson) Ixiolirion holds an isolated and primitive position because of its subumbellate inflorescence and leafy scape; all other genera have flowers solitary or borne in strict umbels and leafless scape. This position is reflected in its karyotype. Chromosomes of Ixiolirion are quite small unlike most other amaryllids which bear large chromosomes (Mehra and Sachdeva 1976). Its karyotype is symmetric with all except one chromosome of the basic set bearing median or submedian centromere. Obviously, creation of a distinct tribe (Ixiolirieae) or subfamily (Ixioliriodeae) to accommodate the single genus Ixiolirion seems to be justified.

Hutchinson (1959) has treated the group Hemerocallideae as a connecting link between Liliaceae and Amaryllidaceae. Regarding Ixiolirion as a primitive genus of the latter it should bear some similarity with Hemerocallideae. This seems to be the case. Hemerocallideae are characterized by plants with rhizomatous or bulblike root stock, basal leaves and a leafy scape bearing hypogynous flowers in a racemose or paniculate inflorescence. The difference in position of ovary not withstanding, Ixiolirion differs from Hemerocallideae only in the degree of leafiness of 
scape and restriction of flowers to more terminal clusters. Cytologically also the two are quite comparable. Karyotype of Hemerocallis, a well worked out genus of Hemerocallideae, consists of a basic set of 11 relatively small chromosomes 8 to 9 of which bear median-submedian centromere (Zadoo et al. 1976). These similarities without necessarily speaking of any direct relationship between the two taxa certainly favour the derivation of at least some primitive epigynous Amaryllidaceae from Hemerocallideae of the Liliaceous stock.

As mentioned earlier species delimitation in Ixiolirion has been quite confusing. Commenting upon I. tataricum Wendelbo (1970) writes “. . . is a variable species. There are all kinds of transitions, and the distribution pattern of different forms does not make any sense". The present record of a hexaploid population throws light on the cause of this infrageneric confusion. With its vegetative mode of reproduction Ixiolirion can accumulate polyploidy regardless of its impact on fertility. Thus a range of euploids upto at least $6 x$ should exist in nature. Being a segmental alloploid the genetic constitution of the basic diploids of the hexaploid must be somewhat different. Hybridization and backcrossing in polyploids can give rise to complexes which range in morphology all the way from one diploid parent to the other. Occasionally they even acquire characters vastly different from either parent (Davis and Heywood 1963). Further, if anaphase I chromosome distribution in the present material is any index, polyploidy widens the spectrum of variability by producing gametes with deviant numbers, some of which on involvement in fertilization may lead to production of aneuploids. Probably a combination of all these factors has resulted in a highly variable genus. Its resolution will require detailed cytomorphological studies on populations from various locations.

\section{Summary}

Genus Ixiolirion is represented in Kashmir by a single species, I. tataricum. Plants collected from Pampore are hexaploid with 72 chromosomes. Karyology and mode of chromosome synapsis during male meiosis indicate that the population is a segmental alloploid. Comparison of karyotypes reveals that the chromosomes of Ixiolirion hardly bear any structural homology with members of either Alstroemerieae or Agaveae. Presence of leafy scape and subumbellate inflorescence alongwith cytological features like very small chromosomes and symmetric karyotype give Ixiolirion a unique and primitive position in Amaryllidaceae (sensu Hutchinson) and justify its treatment into a distinct tribe Ixiolirieae or subfamily Ixiolirioideae. Similarity between Ixiolirion and Hemerocallideae in both plant morphology and chromosome complement supports their placement close to one another. Polyploidy and segregational irregularities during meiosis explain the existence of morphological diversity and consequent taxonomic confusion in the genus.

\section{Acknowledgement}

Authors are grateful to Prof. Y. R. Malhotra for facilities. 


\section{Literature cited}

*Baker, J. G. 1888. Handbook of the Amaryllidaceae. Geo Bell and Sons, London.

Battaglia, E. 1955. Chromosome morphology and terminology. Carylogia 8: 179-187.

Benthem, G. and Hooker, J. D. 1883. Genera Plantarum. Vol. III. L. Reeve and Co., London.

Darlington, C. D. and Wylie, A. P. 1955. Chromosome Atlas of Flowering Plants. George Allen and Unwin, Ltd., London.

Davis, P. H. and Heywood, V. D. 1963. Principles of Angiosperm Taxonomy. Oliver and Boyd, Edinburgh.

Evans, G. M. and Macefield, A. J. 1973. The effect of B-chromosomes on homoeologous pairing in species hybrids I. Lolium temulentum $\times$ Lolium perenne. Chromosoma (Berl.) 41: 6373.

Gilles, A. and Randolph, L. G. 1951. Reduction of quadrivalent frequency in autotetraploid maize during a period of ten years. Amer. J. Bot. 38: 12-17.

*Herbert, W. 1837. Amaryllidaceae. J. Ridgeway, London.

Hutchinson, J. 1959. Families of Flowering Plants. vol. II. Monocotyledons. ed. 2. Oxford, London.

Komarov, V. L. 1935. Flora of the U.S.S.R. Izdatel'stvo Akademii Nauk SSR. Leningrad.

Levan, A. 1940. Meiosis in Allium porrum, a tetraploid species with chiasma localization. Hereditas 26: 454-462.

Mehra, P. N and Sachdeva, S. K. 1976. Cytological observations on some W. Himalayan Monocots IV. Several families. Cytologia 41 : 31-53.

Murin, A. and Sheikh, M. Y. 1971. in Löve, A. IOPB chromosome number reports XXXII. Taxon 20: 349-356.

Nasir, E. 1980. Amaryllidaceae in Nasir, E. and Ali, S. I. Flora of Pakistan 134: 1-7.

Riley, R. and Chapman, V. 1958. The genetic control of the cytologically diploid behaviour of hexaploid wheat. Nature 182: 713-715.

Satô, D. 1938. Karyotype alteration and phylogeny IV. Karyotype in Amaryllidaceae with special reference to the SAT-chromosome. Cytologia 9: 203-242.

Stebbins, G. L. 1950. Variation and Evolution in Plants. Columbia Univ. Press, New York.

- 1971. Chromosomal Evolution in Higher Plants. Edward Arnold Ltd., London.

Takhtajan, A. L. 1980. Outline of the classification of flowering plants (Magnoliophyta). Bot. Rev. 46: 225-359.

Traub, H. P. 1942. The Ixiolirion tribe. Herbertia 9: 53-59.

- 1957. Classification of the Amaryllidaceae-subfamilies, tribes and genera. Plant Life 13: 76-83.

Wendelbo, P. 1970. Amaryllidaceae in Rechinger, K. H. Flora Iranica. Academische Druck-V. Verlagsanstalt Graz, Austria.

Zadoo, S. N. Roy, R. P. and Khoshoo, T. N. 1976. Variation in karyotype in Hemerocallis. La Cellule $71: 253-271$.

* Not seen in original. 